\title{
BOOKS BY PAUL GILES
}

Hart Crane: The Contexts of The Bridge (1986)

American Catholic Arts and Fictions: Culture, Ideology, Aesthetics (1992)

Transatlantic Insurrections: British Culture and the Formation of American Literature, I730-I860 (200I)

Virtual Americas: Transnational Fictions and the Transatlantic Imaginary (2002)

Atlantic Republic: The American Tradition in English Literature (2006)

The Global Remapping of American Literature (20I I) 
Paul Giles is Challis Professor of English Literature at the University of Sydney 